\title{
Synthesis of a tricyclic lactam via Beckmann rearrangement and ring-rearrangement metathesis as key steps
}

\author{
Sambasivarao Kotha*, Ongolu Ravikumar and Jadab Majhi
}

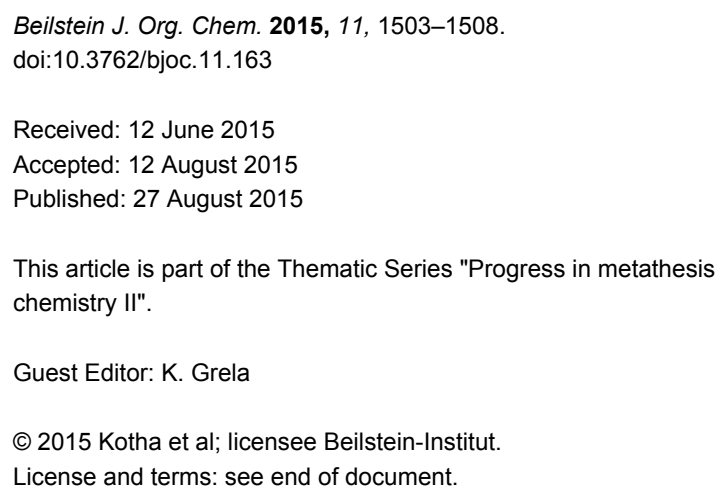

Beilstein J. Org. Chem. 2015, 11, 1503-1508.

doi:10.3762/bjoc.11.163

Received: 12 June 2015

Accepted: 12 August 2015

Published: 27 August 2015

This article is part of the Thematic Series "Progress in metathesis chemistry II".

Guest Editor: K. Grela

(c) 2015 Kotha et al; licensee Beilstein-Institut.

License and terms: see end of document.

allylation; Beckmann rearrangement; lactams; oximes;

ring-rearrangement metathesis

\begin{abstract}
A tricyclic lactam is reported in a four step synthesis sequence via Beckmann rearrangement and ring-rearrangement metathesis as key steps. Here, we used a simple starting material such as dicyclopentadiene.
\end{abstract}

\section{Introduction}

The Beckmann rearrangement (BR), a well-known protocol for the conversion of ketoxime to an amide in the presence of acid was discovered in 1886. This rearrangement involves the migration of a group anti to the leaving group on the nitrogen atom. The BR has widely been used in synthetic organic chemistry, for example, a large-scale production of Nylon- 6 is based on the synthesis of $\varepsilon$-caprolactam from cyclohexanone oxime involving the BR. The activation energy for the BR is almost the same as that of the nucleophilic substitution at $\mathrm{sp}^{2}$ nitrogen. To synthesize various aza-arenes and cyclic imines, such as quinolines, aza-spiro compounds and dihydropyrroles, the intramolecular $\mathrm{S}_{\mathrm{N}}$ 2-type reaction at the oxime nitrogen is useful [1-6]. Here, we plan to use the BR in combination with a ringrearrangement metathesis (RRM) [7-24] to generate lactam derivative 1 . The RRM protocol involves a tandem process with several metathetic transformations such as ring-closing metathesis (RCM) and ring-opening metathesis (ROM). The RRM has emerged as a powerful tool in organic synthesis because of its ability to transform simple starting materials into complex targets involving an ingenious design. The retrosynthetic strategy to the target molecule $\mathbf{1}$ is shown in Figure 1. RRM of the tricyclic allylated compound $\mathbf{2}$ can deliver the target lactam $\mathbf{1}$. The key synthon $\mathbf{2}$ can be derived by allylation of lactam 3, which in turn can be prepared via BR starting with the known enone 4 [25-27], derived from dicyclopentadiene (5) [28-30].

\section{Results and Discussion}

To begin with, the oxidation of dicyclopentadiene (5) in the presence of $\mathrm{SeO}_{2}$ gave $1 \alpha$-dicyclopentadienol (6), which on 


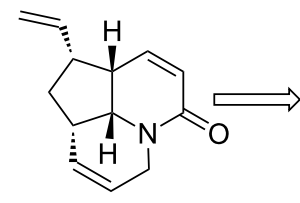

1

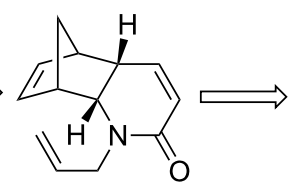

2<smiles>O=C1C=C[C@H]2C3C=CC[C@H]3C(=O)C=C[C@H]2N1</smiles>

3<smiles>O=C1C=C[C@H]2C3C=C[C@H](C3)[C@H]2C1=O</smiles><smiles>[Mg][Mg]</smiles>

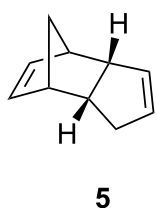

Figure 1: Retrosynthetic analysis of tricyclic amide 1.

treatment with pyridinium chlorochromate (PCC) [31] delivered the known tricyclic enone 4 . Selective reduction of enone $\mathbf{4}$ with $\mathrm{Zn}$ in $\mathrm{AcOH} / \mathrm{EtOH}$ under reflux conditions gave the saturated ketone 7 [32] (Scheme 1).

Later, tricyclic ketone 7 was reacted with $\mathrm{NH}_{2} \mathrm{OH} \cdot \mathrm{HCl}$ in the presence of $\mathrm{NaOAc}$ in dry $\mathrm{MeOH}$ at $\mathrm{rt}$ to give a mixture of oximes $\mathbf{8 a}$ and $\mathbf{8 b}$ and this mixture was subjected to a $\mathrm{BR}$ under different reaction conditions, like (a) $p$ - TsCl, rt, $15 \mathrm{~h}, \mathrm{CH}_{3} \mathrm{CN}$ (b) $p$ - $\mathrm{TsCl}$, reflux, $15 \mathrm{~h}, \mathrm{CH}_{3} \mathrm{CN}$ (c) PPA, reflux for $20 \mathrm{~min}$. Surprisingly, in all these instances no rearrangement product was observed. Interestingly, when the mixture of oximes $8 \mathbf{a}$ and $\mathbf{8 b}$ was treated with $\mathrm{TsCl}$ in the presence of $\mathrm{NaOH}$ at rt lactams 9a and 9b were obtained in $66 \%$ combined yield for two steps $(9 \mathbf{a}: 9 \mathbf{b}=2: 1)$ (Scheme 2) but the products were inseparable by column chromatography. Next, we attempted to separate the mixture of these isomers (9a and $\mathbf{9 b}$ ) by selective crystallization using different solvent systems. Finally, one of the lactam derivative 9a $(\delta=3.86$, dd, $J=5.8,2.9 \mathrm{~Hz}, 1 \mathrm{H})$ was isolated in pure form from ethanol in $20 \%$ yield over two steps.

Subsequently, we attempted to synthesize the desired lactam 9a via Schmidt reaction or BR of the keto derivative 7 in a single step. In this regard, the tricyclic ketone 7 was treated under different reaction conditions. These include: (a) $\mathrm{NaN}_{3}$, heat 1 day in TFA (b) $\mathrm{NaN}_{3}, \mathrm{FeCl}_{3}$ in DCE at rt and reflux, 1 day and (c) $\mathrm{TMSN}_{3}, \mathrm{FeCl}_{3}$ in DCE, 1 day. Surprisingly, the desired lactam 9a was not formed. Interestingly, when the tricyclic ketone 7 was treated with hydroxylamine- $O$-sulfonic acid $\left(\mathrm{NH}_{2} \mathrm{OSO}_{3} \mathrm{H}\right)$ in glacial $\mathrm{AcOH}$ under reflux conditions, the lactams $9 \mathbf{a}$ and $9 \mathbf{b}$ were obtained in $48 \%$ yield $(9 \mathbf{a}: 9 \mathbf{b}=2: 1)$ the ratio of oximes $9 \mathbf{a}$ and $\mathbf{9 b}$ was calculated based on ${ }^{1} \mathrm{H}$ NMR spectral data (Scheme 3).

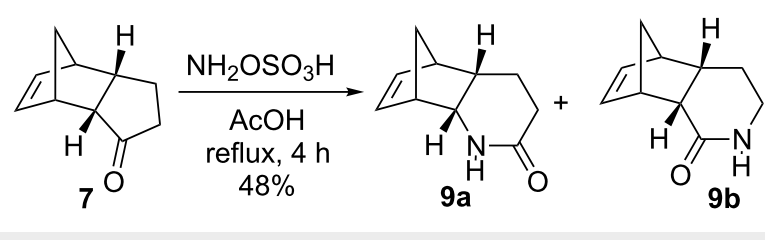

Scheme 3: Beckmann rearrangement reaction in a single step.

Having prepared the lactams $9 \mathbf{a}$ and $\mathbf{9 b}$, the allylation reaction was attempted with the lactam mixture in the presence of $\mathrm{NaH} /$ allyl bromide in dry DMF to generate allyl derivatives 10a and 10b in $84 \%$ yield. Later, without separation of allyl lactams 10a and $\mathbf{1 0 b}$, RRM was attempted with the lactam mixture under different catalyst conditions. For example, reaction conditions

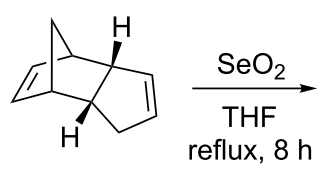

5

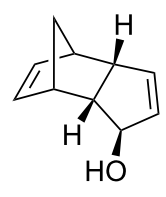

$6(80 \%)$

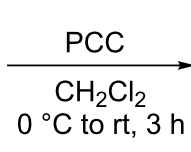

$\left.\right|_{0} ^{1}$

$4(86 \%)$

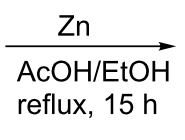

reflux, $15 \mathrm{~h}$

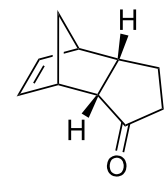

$7(90 \%)$

Scheme 1: Synthesis of tricyclic ketone 4.

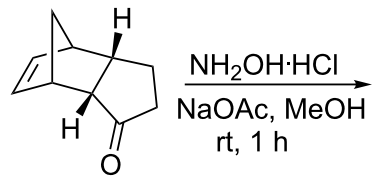

7

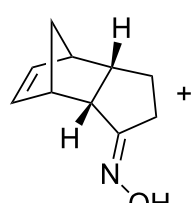

$8 \mathbf{a}$

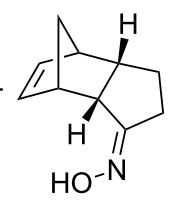

$8 b$

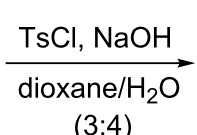

(3:4)

$\mathrm{rt}, 15 \mathrm{~h}$ $66 \%$ (two steps)

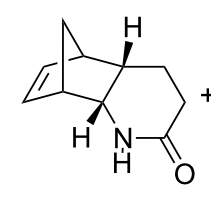

$9 a$

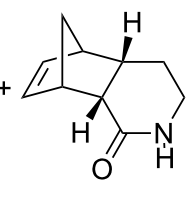

9b

Scheme 2: Beckmann rearrangement of oximes $\mathbf{8 a}$ and $\mathbf{8 b}$. 
such as: (a) G-I in dry $\mathrm{CH}_{2} \mathrm{Cl}_{2}$, under ethylene atmosphere at $\mathrm{rt}$; (b) G-II in dry $\mathrm{CH}_{2} \mathrm{Cl}_{2}$, under ethylene atmosphere at $\mathrm{rt}$ and (c) G-I and G-II in dry toluene under ethylene atmosphere did not deliver the desired RRM product 1a (Scheme 4).

Separation of the required isomer from the mixture of oximes 8a and $8 \mathbf{b}$ or the lactams $9 \mathbf{a}$ and $9 \mathbf{b}$ was not possible by column chromatography because of the same $R_{\mathrm{f}}$ value of the individual compounds. Finally, isolation of the required lactam 9a from the mixture was accomplished by using crystallization. Since this method is cumbersome, an alternate method was attempted. To this end, we changed our synthetic route and tried to use the unsaturated ketone $\mathbf{4}$ and hoped for a different outcome during the BR. In this content, oximation of the enone 4 was carried out with $\mathrm{NH}_{2} \mathrm{OH} \cdot \mathrm{HCl}$ in the presence of $\mathrm{NaOAc}$ in dry $\mathrm{MeOH}$. The stereoisomeric oximes, i.e., (E)-11b and (Z)-11a were separated by silica gel column chromatography to deliver $47 \%$ and $23 \%$ yields, respectively (Scheme 5).

When the oxime 11a was treated with $\mathrm{TsCl}$ in the presence of $\mathrm{NaOH}$ in dioxane/ $\mathrm{H}_{2} \mathrm{O}(3: 4 \mathrm{v} / \mathrm{v})$ at $\mathrm{rt}$ lactam 12 was formed in $34 \%$ yield. However, the oxime $11 \mathrm{~b}$ did not give the rearranged product under the same reaction conditions, which clearly indicates that the oxime 11b is unreactive towards BR (Scheme 6). The stereostructure of the oxime 11b has been determined by single crystal X-ray diffraction data (Figure 2) [33].

Allylation of lactam 12 in the presence of $\mathrm{NaH} /$ allyl bromide in dry DMF gave the allyl derivative $\mathbf{2}$ in $80 \%$ yield. Finally, the RRM of compound $\mathbf{2}$ was accomplished with G-II catalyst in dry $\mathrm{CH}_{2} \mathrm{Cl}_{2}$, under ethylene atmosphere at $\mathrm{rt}$ in the presence of

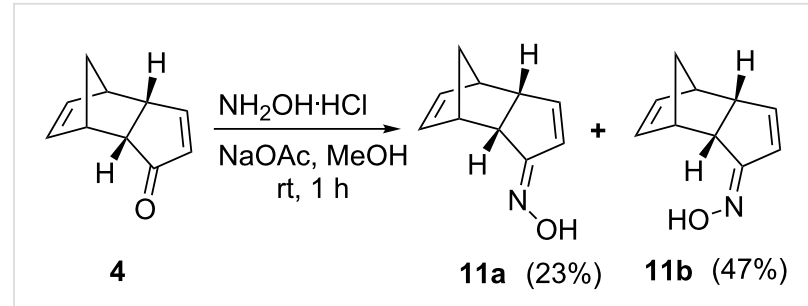

Scheme 5: Synthesis of Beckmann rearrangement precursors.

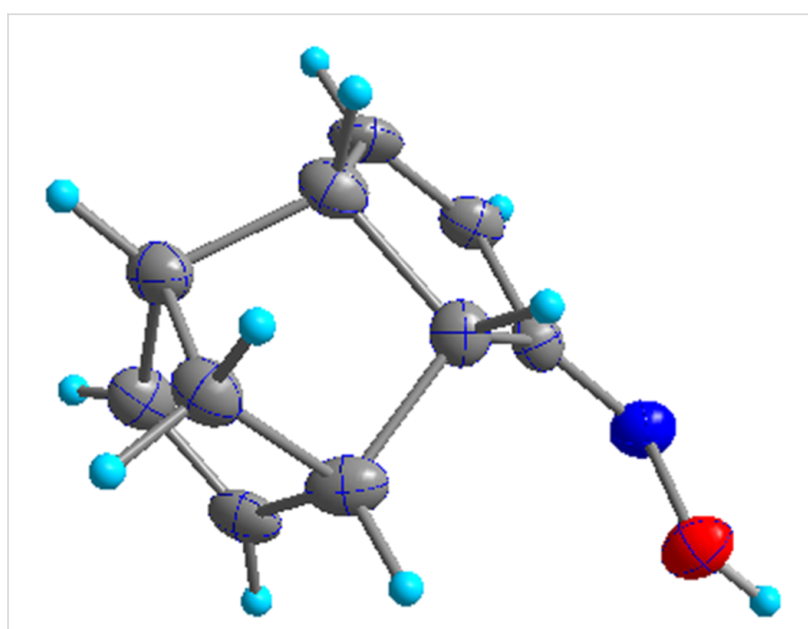

Figure 2: Molecular crystal structure of compound 11b.

$\mathrm{Ti}(\mathrm{OiPr})_{4}$ to deliver the tricyclic compound $\mathbf{1}$ in $90 \%$ yield (Scheme 7). Its structure has been established on the basis of ${ }^{1} \mathrm{H}$ NMR and ${ }^{13} \mathrm{C}$ NMR spectral data and further supported by HRMS data.

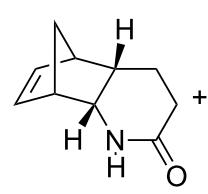

$9 a$
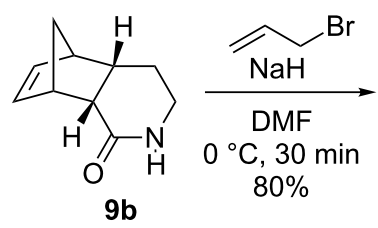

$80 \%$
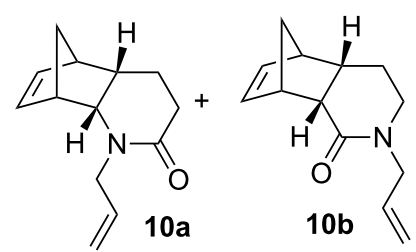

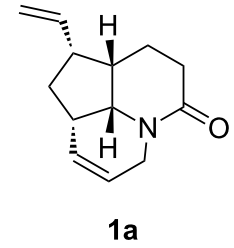

Scheme 4: Synthesis of ring-rearrangement precursors.

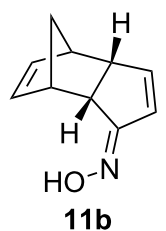

$\underset{\text { dioxane } / \mathrm{H}_{2} \mathrm{O}}{\stackrel{\mathrm{TsCl}}{\mathrm{NaOH}}}$ No product

(3:4)

$\mathrm{rt}, 15 \mathrm{~h}$

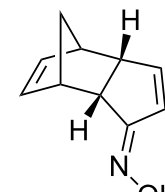

$\underset{\text { dioxane } / \mathrm{H}_{2} \mathrm{O}}{\stackrel{\mathrm{TsCl}}{\mathrm{NaOH}}}$

$(3: 4)$

rt, $15 \mathrm{~h}$

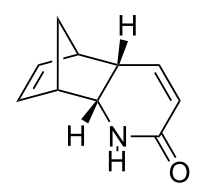

$12(34 \%)$ 


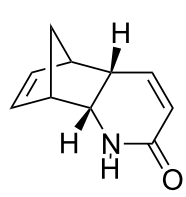

12

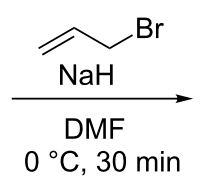

$0{ }^{\circ} \mathrm{C}, 30 \mathrm{~min}$

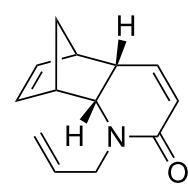

$2(80 \%)$
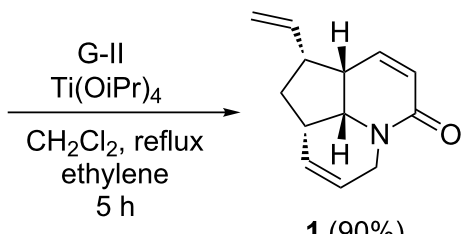

$1(90 \%)$

Scheme 7: Synthesis of aza tricyclic compound 1 by RRM.

\section{Conclusion}

In summary, we have demonstrated the RRM strategy with the norbornene derivative $\mathbf{2}$ to deliver the tricyclic compound $\mathbf{1}$ involving a short synthetic sequence. However, a similar compound 10a did not deliver the RRM product. For the first time, we have demonstrated that BR in combination with RRM is a useful strategy to generate azacyclic compounds. Here we have used an inexpensive starting material such as dicyclopentadiene (5).

\section{Experimental}

\section{Synthesis of compounds $\mathbf{9 a}$ and $\mathbf{9 b}$}

Method 1: Analogously as described in [4], a mixture of 7 (2 g, $13.51 \mathrm{mmol})$, hydroxylamine hydrochloride $(1.41 \mathrm{~g}$, $20.27 \mathrm{mmol}), \mathrm{NaOAc}(1.66 \mathrm{~g}, 20.27 \mathrm{mmol})$ and methanol $(50 \mathrm{~mL})$ was stirred at $\mathrm{rt}$ for $1 \mathrm{~h}$. The residue after evaporation of the solvent was diluted with water and extracted with ether. Removal of ether furnished the crude oxime $(2.4 \mathrm{~g})$. $p$-Toluenesulfonyl chloride $(6.15 \mathrm{~g}, 32.28 \mathrm{mmol})$ was added portion-wise over $15 \mathrm{~min}$ to a stirred solution of the crude oxime $(2.4 \mathrm{~g})$ and $\mathrm{NaOH}(2.97$ g. $74.44 \mathrm{mmol})$ in $150 \mathrm{~mL}$ dioxane/water 3:4 at $5{ }^{\circ} \mathrm{C}$. The mixture was stirred at $\mathrm{rt}$ for $15 \mathrm{~h}$ and dioxane was removed in vacuo. The residue was dissolved in $\mathrm{CH}_{2} \mathrm{Cl}_{2}$ and washed with brine. Removal of the solvent and column chromatography gave a mixture of amide isomers $(\mathbf{9 a}, \mathbf{9 b})$ $(1.45 \mathrm{~g}, 66 \%)$. The amide mixture was crystalized in different solvents and finally one of isomer 9a was isolated from ethanol $20 \%$.

Method 2: A mixture of $7(100 \mathrm{mg}, 0.68 \mathrm{mmol})$ and hydroxylamine-O-sulfonic acid (113 mg, $1.0 \mathrm{mmol})$ in $\mathrm{AcOH}(5 \mathrm{~mL})$ was heated at reflux conditions for $4 \mathrm{~h}$ under nitrogen. After completion of the reaction (TLC monitoring), the reaction mixture was basified with $3 \mathrm{~N} \mathrm{NaOH}$ solution and the organic layer was extracted with $\mathrm{CH}_{2} \mathrm{Cl}_{2}$, washed with water, brine and dried by $\mathrm{Na}_{2} \mathrm{SO}_{4}$. The combined organic layer was concentrated under reduced pressure and column chromatography gave a mixture of amide isomers $9 \mathbf{a}$ and $9 \mathbf{b}$ (1.06 g, $48 \%$ ). The amide mixture was crystalized in different solvents and finally isomer 9a was isolated from ethanol. White solid 9a; $\mathrm{mp}=150-155^{\circ} \mathrm{C}$; yield 15\%: $R_{\mathrm{f}}=0.30($ EtOAc/pentane $1: 1$ v/v); IR (neat): 3195 (m), 3067 (w), 2938 (s), 2868 (m), 1674 (s), $1627(\mathrm{~m}), 1452$ (w), $1434(\mathrm{w}), 1410(\mathrm{~m}), 1333(\mathrm{~m}), 1252$ (w), $1201(\mathrm{~m}), 1031(\mathrm{w}), 783(\mathrm{~m}), 541(\mathrm{~m}) \mathrm{cm}^{-1} ;{ }^{1} \mathrm{H}$ NMR (400 $\left.\mathrm{MHz}, \mathrm{CDCl}_{3}\right) \delta 6.31(\mathrm{~s}, 1 \mathrm{H}), 6.22(\mathrm{dd}, J=5.8,3.0 \mathrm{~Hz}, 1 \mathrm{H})$, $6.10(\mathrm{dd}, J=5.8,3.0 \mathrm{~Hz}, 1 \mathrm{H}), 3.86,(\mathrm{dd}, J=5.8,2.9 \mathrm{~Hz}, 1 \mathrm{H})$, $2.97(\mathrm{~s}, 1 \mathrm{H}), 2.88(\mathrm{~s}, 2 \mathrm{H}), 2.48-2.40(\mathrm{~m}, 1 \mathrm{H}), 2.13-2.05$ $(\mathrm{m}, 1 \mathrm{H}), 1.94-1.87(\mathrm{~m}, 1 \mathrm{H}), 1.56(\mathrm{dt}, J=8.8,1.8 \mathrm{~Hz}, 1 \mathrm{H}), 1.42$ $(\mathrm{d}, J=8.8 \mathrm{~Hz}, 1 \mathrm{H}), 1.23-1.13(\mathrm{~m}, 1 \mathrm{H}) \mathrm{ppm} ;{ }^{13} \mathrm{C} \mathrm{NMR}(100$ $\left.\mathrm{Hz}, \mathrm{CDCl}_{3}\right) \delta 175.5,137.6,134.2,54.8,48.0,47.8,46.5,39.49$, 31.4, $23.2 \mathrm{ppm}$.

\section{Synthesis of compounds $11 \mathrm{a}$ and $\mathbf{1 1 b}$}

Analogously as described in [4], a mixture of 4 (9 g, $61.64 \mathrm{mmol})$, hydroxylamine hydrochloride $(6.41 \mathrm{~g}$, $92.34 \mathrm{mmol}), \mathrm{NaOAc}(7.58 \mathrm{~g}, 92.49 \mathrm{mmol})$ and methanol $(225 \mathrm{~mL})$ were stirred at $\mathrm{rt}$ for $1 \mathrm{~h}$. The residue after evaporation of the solvent was diluted with water and extracted with diethyl ether. Removal of ether furnished the crude oxime which was purified by silica gel column chromatography by eluting appropriate mixture of ethyl acetate/petroleum ether to afford compounds $\mathbf{1 1 a}(2.29 \mathrm{~g}, 23 \%)$ and $\mathbf{1 1 b}(4.61 \mathrm{~g}, 47 \%)$ as colourless solids.

11a: $R_{\mathrm{f}}=0.29($ EtOAc/pentane $2: 8 \mathrm{v} / \mathrm{v}) ;$ IR (neat): $3325(\mathrm{~m})$, 3013 (m), $2400(\mathrm{w}), 1725$ (w), 1337 (w), 1216 (m), 927 (m), $759(\mathrm{~s}) \mathrm{cm}^{-1} ;{ }^{1} \mathrm{H}$ NMR $\left(500 \mathrm{MHz}, \mathrm{CDCl}_{3}\right) \delta 9.15(\mathrm{~s}, 1 \mathrm{H}), 6.54$ $(\mathrm{dd}, J=5.8,1.3 \mathrm{~Hz}, 1 \mathrm{H}), 6.38(\mathrm{dd}, J=5.8,2.5 \mathrm{~Hz}, 1 \mathrm{H}), 5.97$ (dd, $J=5.6,2.8 \mathrm{~Hz}, 1 \mathrm{H}), 5.77(\mathrm{dd}, J=5.6,2.9 \mathrm{~Hz}, 1 \mathrm{H}), 3.32$ (m, 1H), $3.18(\mathrm{dd}, J=10.7,4.5 \mathrm{~Hz}, 1 \mathrm{H}), 3.16(\mathrm{~s}, 1 \mathrm{H}), 2.28$ (s, 1H), 2.90 (s, 1H), 1.61 (d, $J=8.3 \mathrm{~Hz}, 1 \mathrm{H}), 1.47$ (d, $J=8.3 \mathrm{~Hz}$, 1H) ppm; ${ }^{13} \mathrm{C}$ NMR $\left(125 \mathrm{~Hz}, \mathrm{CDCl}_{3}\right) \delta 165.1,149.1,133.3$, 133.1, 126.4, 51.0, 50.5, 46.1, 45.9, 44.1 ppm; HRMS (Q-Tof) $m / z:[\mathrm{M}+\mathrm{Na}]^{+}$calcd for $\mathrm{C}_{10} \mathrm{H}_{11} \mathrm{NNaO}, 184.0733$; found, 184.0734 .

11b: $\mathrm{mp}=89-91{ }^{\circ} \mathrm{C} ; R_{\mathrm{f}}=0.30($ EtOAc/petroleum ether $2: 8$ v/v); IR (neat): 3322 (m), 3020 (m), 2396 (w), 2125 (w), 1705 (m), $1217(\mathrm{~m}), 926(\mathrm{~m}), 759(\mathrm{~s}) \mathrm{cm}^{-1} ;{ }^{1} \mathrm{H}$ NMR (500 MHz, $\left.\mathrm{CDCl}_{3}\right) \delta 8.71(\mathrm{~s}, 1 \mathrm{H}), 6.30(\mathrm{dd}, J=5.8,2.5 \mathrm{~Hz}, 1 \mathrm{H}), 6.00(\mathrm{dd}$, $J=5.7,1.3 \mathrm{~Hz}, 1 \mathrm{H}), 5.90(\mathrm{dd}, J=5.6,3.0 \mathrm{~Hz}, 1 \mathrm{H}), 5.76(\mathrm{dd}, J$ $=5.6,2.9 \mathrm{~Hz}, 1 \mathrm{H}), 3.43(\mathrm{~s}, 1 \mathrm{H}), 3.35(\mathrm{dd}, J=6.1,4.2 \mathrm{~Hz}, 1 \mathrm{H})$, 
$3.30(\mathrm{~m}, 1 \mathrm{H}), 2.90(\mathrm{~s}, 1 \mathrm{H}), 1.64(\mathrm{~d}, J=8.3 \mathrm{~Hz}, 1 \mathrm{H}), 1.50(\mathrm{~d}, J=$ $8.3,1 \mathrm{H}) \mathrm{ppm} ;{ }^{13} \mathrm{C}$ NMR $\left(125 \mathrm{~Hz}, \mathrm{CDCl}_{3}\right) \delta 168.1,147.0$, 133.1, 132.9, 131.1, 51.9, 50.8, 45.1, 45.0, 44.1 ppm; HRMS (Q-Tof) $m / z:[\mathrm{M}+\mathrm{Na}]^{+}$calcd for $\mathrm{C}_{10} \mathrm{H}_{11} \mathrm{NNaO}, 184.0733$; found, 184.0737 .

\section{Synthesis of compound $\mathbf{1 2}$}

Analogously as described in [4], $p$-toluenesulfonyl chloride (2.36 g, $12.42 \mathrm{mmol}$ ) was added portionwise over $15 \mathrm{~min}$ to a stirred solution of oxime 11a $(1.0 \mathrm{~g}, 6.21 \mathrm{mmol})$ and $\mathrm{NaOH}$ (1.24 g. $31.05 \mathrm{mmol}$ ) in $100 \mathrm{~mL}$ dioxane/water $3: 4$ at $5{ }^{\circ} \mathrm{C}$. The mixture was stirred at $\mathrm{rt}$ for $15 \mathrm{~h}$ and the dioxane was removed in vacuo. The residue was dissolved in $\mathrm{CH}_{2} \mathrm{Cl}_{2}$ and washed with the brine. Removal of solvent and column chromatography using an appropriate mixture of ethyl acetate/petroleum ether gave the pure lactam $12(0.33 \mathrm{~g}, 34 \%)$ as a semi solid. IR (neat): 3020 (m), 2400 (w), 2125 (w), 1678 (w), 1422 (w), 1216 (m), 1049 (w), 1022 (w), 929 (w), 759 (s) cm ${ }^{-1} ;{ }^{1} \mathrm{H}$ NMR (500 $\left.\mathrm{MHz}, \mathrm{CDCl}_{3}\right) \delta 6.36-6.34(\mathrm{~m}, 1 \mathrm{H}), 6.15(\mathrm{dd}, J=5.5,3 \mathrm{~Hz}$, $1 \mathrm{H}), 6.07(\mathrm{dd}, J=5.5,3 \mathrm{~Hz}, 1 \mathrm{H}), 5.96(\mathrm{bs}, 1 \mathrm{H}), 5.63(\mathrm{dt}, J=$ $8.5,2 \mathrm{~Hz}, 1 \mathrm{H}), 4.12-4.08(\mathrm{~m}, 1 \mathrm{H}), 3.10(\mathrm{t}, J=0.5 \mathrm{~Hz}, 1 \mathrm{H}), 3.06$ $(\mathrm{d}, J=0.5 \mathrm{~Hz}, 1 \mathrm{H}), 2.99-2.95(\mathrm{~m}, 1 \mathrm{H}), 1.44(\mathrm{dt}, J=8.5,2 \mathrm{~Hz}$, $1 \mathrm{H}), 1.25-1.22(\mathrm{~m}, 1 \mathrm{H}) \mathrm{pmm} ;{ }^{13} \mathrm{C} \mathrm{NMR}\left(125 \mathrm{~Hz}, \mathrm{CDCl}_{3}\right) \delta$ $164.4,142.4,136.9,134.5,122.4,54.9,49.8,47.8,44.5,39.3$ ppm; HRMS (Q-Tof) $m / z$ : $[\mathrm{M}+\mathrm{Na}]^{+}$calcd for $\mathrm{C}_{10} \mathrm{H}_{11} \mathrm{NNaO}$, 184.0733; found, 184.0733 .

\section{Synthesis of compound 2}

Analogously as described in [8], a suspension of $\mathrm{NaH}$ (20 mg, $0.83 \mathrm{mmol})$ in dry DMF $(5 \mathrm{~mL})$, was added to compound 12 (70 mg, $0.43 \mathrm{mmol})$ in dry DMF $(5 \mathrm{~mL})$ and allyl bromide $\left(57 \mathrm{mg}, 0.47 \mathrm{mmol}\right.$ ) at $0{ }^{\circ} \mathrm{C}$ under nitrogen and it was stirred for 20 minutes at $0{ }^{\circ} \mathrm{C}$. After completion of the reaction (TLC monitoring) the reaction mixture was acidified with saturated ammonium chloride and extracted with ethyl acetate. The combined organic layer was washed with water and brine and then dried over sodium sulfate. Later, the organic layer was concentrated under reduced pressure and purified by silica gel column chromatography by eluting with an appropriate mixture of ethyl acetate/petroleum ether to afford compound $\mathbf{2}$ as a brown liquid (87 mg, 80\%). IR (neat): 3370 (s), 2945 (m), 2832 (m), 2532 (w), $2044(\mathrm{w}), 1662(\mathrm{w}), 1450$ (m), $1114(\mathrm{~m}), 1030$ (s), $770(\mathrm{~m}) \mathrm{cm}^{-1} ;{ }^{1} \mathrm{H} \mathrm{NMR}\left(500 \mathrm{MHz}, \mathrm{CDCl}_{3}\right) \delta 6.25-6.23$ $(\mathrm{m}, 1 \mathrm{H}), 6.05-6.01(\mathrm{~m}, 2 \mathrm{H}), 5.85-5.77(\mathrm{~m}, 1 \mathrm{H}), 5.67(\mathrm{dd}, J=$ $10,2 \mathrm{~Hz}, 1 \mathrm{H}), 5.26-5.22(\mathrm{~m}, 2 \mathrm{H}), 4.47-4.46(\mathrm{~m}, 1 \mathrm{H}), 4.02(\mathrm{dd}$, $J=10,3.5 \mathrm{~Hz}, 1 \mathrm{H}), 3.65-3.60(\mathrm{~m}, 1 \mathrm{H}), 3.29(\mathrm{~s}, 1 \mathrm{H}), 3.08(\mathrm{~s}$, $1 \mathrm{H}), 3.01-2.97(\mathrm{~m}, 1 \mathrm{H}), 1.45$ (dt, $J=9,2 \mathrm{~Hz}, 1 \mathrm{H}), 1.21-1.24$ (m, 1H) ppm; ${ }^{13} \mathrm{C} \mathrm{NMR}\left(125 \mathrm{~Hz}, \mathrm{CDCl}_{3}\right) \delta 162.5,140.1,137.1$, 133.8, 133.6, 123.1, 117.7, 59.43, 48.4, 47.4, 47.3, 44.7, 40.0 ppm; HRMS (Q-Tof) $m / z$ : $[\mathrm{M}+\mathrm{Na}]^{+}$calcd for $\mathrm{C}_{13} \mathrm{H}_{15} \mathrm{NNaO}$, 224.1046; found, 224.1041.

\section{Synthesis of compound 1}

Analogously as described in [8], to a stirred solution of compound $2(20 \mathrm{mg}, 0.099 \mathrm{mmol})$ in dry $\mathrm{CH}_{2} \mathrm{Cl}_{2}(20 \mathrm{~mL})$ degassed with nitrogen for 10 minutes, purged with ethylene gas for 10 minutes was then added $\mathrm{Ti}(\mathrm{OiPr})_{4}$ and Grubbs-II catalyst $(8.4 \mathrm{mg}, 10 \mathrm{~mol} \%)$ and stirred for $5 \mathrm{~h}$ at reflux conditions under ethylene atmosphere. After completion of the reaction (TLC monitoring) the solvent was removed on a rotavapor under reduced pressure and purified by silica gel column chromatography by eluting with an appropriate mixture of ethyl acetate/petroleum ether to afford $\mathbf{1}$ as a brown coloured semi solid (18 mg, 90\%). IR (neat): 3020 (m), 2927 (m), 2861 (m), $2396(\mathrm{w}), 1727(\mathrm{w}), 1608(\mathrm{w}), 1461(\mathrm{w}), 1216(\mathrm{~m}), 929(\mathrm{w})$, $762(\mathrm{~s}) \mathrm{cm}^{-1} ;{ }^{1} \mathrm{H}$ NMR $\left(500 \mathrm{MHz}, \mathrm{CDCl}_{3}\right) \delta 6.35-6.27(\mathrm{~m}$, $1 \mathrm{H}), 6.05-5.89(\mathrm{~m}, 1 \mathrm{H}), 5.88-5.83(\mathrm{~m}, 1 \mathrm{H}), 5.75-5.72(\mathrm{~m}, 1 \mathrm{H})$, $5.63(\mathrm{dt}, J=16.0,9.7 \mathrm{~Hz}, 1 \mathrm{H}), 5.02-4.91(\mathrm{~m}, 2 \mathrm{H}), 4.64-4.57$ $(\mathrm{m}, 1 \mathrm{H}), 4.07-4.03(\mathrm{~m}, 1 \mathrm{H}), 3.50-3.42(\mathrm{~m}, 1 \mathrm{H}), 3.19-3.14(\mathrm{~m}$, $1 \mathrm{H}), 3.12-2.94(\mathrm{~m}, 1 \mathrm{H}), 2.62-2.55(\mathrm{~m}, 1 \mathrm{H}), 2.21-2.03(\mathrm{~m}, 1 \mathrm{H})$, $1.62-1.53(\mathrm{~m}, 1 \mathrm{H}) \mathrm{ppm} ;{ }^{13} \mathrm{C} \mathrm{NMR}\left(125 \mathrm{~Hz}, \mathrm{CDCl}_{3}\right) \delta 164.2$, 139.6, 139.6, 125.7, 123.5, 123.2, 115.5, 59.0, 58.8, 49.1, 42.3, 40.9, $39.6 \mathrm{ppm}$; HRMS (Q-Tof) $\mathrm{m} / z$ : $[\mathrm{M}+\mathrm{Na}]^{+}$calcd for $\mathrm{C}_{13} \mathrm{H}_{15} \mathrm{NNaO}$, 224.1046; found, 224.1041.

\section{Supporting Information}

\section{Supporting Information File 1}

NMR spectra of synthesized compounds and X-ray data of compound $\mathbf{1 1 b}$.

[http://www.beilstein-journals.org/bjoc/content/ supplementary/1860-5397-11-163-S1.pdf]

\section{Acknowledgements}

We thank the Department of Science and Technology (DST), New Delhi for the financial support and the Sophisticated Analytical Instrument Facility (SAIF), IIT-Bombay for recording spectral data and also thank Gaddamedi Sreevani and Darshan Mhatre for their help in collecting the X-ray data and structure refinement. S. K. thanks the Department of Science and Technology for the award of a J. C. Bose fellowship. O. R. thanks the University Grants Commission, New Delhi for the award of a research fellowship. J. M thanks DST for the award of inspire fellowship.

\section{References}

1. Beckmann, E. Ber. Dtsch. Chem. Ges. 1886, 19, 988. doi:10.1002/cber.188601901222

2. Blatt, A. H. Chem. Rev. 1933, 12, 215. doi:10.1021/cr60042a002

3. Chandrasekhar, S. The Beckmann and Related Reactions. In Comprehensive Organic Synthesis II; Knochel, P.; Molander, G. A., Eds.; Elsevier, 2014; Vol. 7, pp $770 \mathrm{ff}$. doi:10.1016/B978-0-08-097742-3.00730-8 
4. Mehta, G.; Praveen, M. J. Org. Chem. 1995, 60, 279. doi:10.1021/jo00106a052

5. Kaur, N.; Sharma, P.; Kishore, D. J. Chem. Pharm. Res. 2012, 4, 1938.

6. Narasaka, K.; Kitamura, M. Eur. J. Org. Chem. 2005, 4505. doi:10.1002/ejoc.200500389

7. Kotha, S.; Dipak, M. K. Tetrahedron 2012, 68, 397. doi:10.1016/j.tet.2011.10.018

8. Kotha, S.; Ravikumar, O. Eur. J. Org. Chem. 2014, 5582. doi:10.1002/ejoc.201402273

9. Kotha, S.; Ravikumar, O. Tetrahedron Lett. 2014, 55, 5781. doi:10.1016/j.tetlet.2014.08.108

10. Zuercher, W. J.; Hashimoto, M.; Grubbs, R. H. J. Am. Chem. Soc. 1996, 118, 6634. doi:10.1021/ja9606743

11. Beligny, S.; Eibauer, S.; Maechling, S.; Blechert, S. Angew. Chem., Int. Ed. 2006, 45, 1900. doi:10.1002/anie.200503552

12. Holub, N.; Blechert, S. Chem. - Asian J. 2007, 2, 1064. doi:10.1002/asia.200700072

13. Li, J.; Lee, D. Eur. J. Org. Chem. 2011, 4269. doi:10.1002/ejoc.201100438

14. Kotha, S.; Singh, K. Eur. J. Org. Chem. 2007, 5909. doi:10.1002/ejoc.200700744

15. Carreras, J.; Avenoza, A.; Busto, J. H.; Peregrina, J. M. J. Org. Chem. 2011, 76, 3381. doi:10.1021/jo200321t

16. North, M.; Banti, D. Adv. Synth. Catal. 2002, 344, 694.

17. Scholl, M.; Ding, S.; Lee, C. W.; Grubbs, R. H. Org. Lett. 1999, 1, 953. doi:10.1021/ol990909q

18. Nguyen, N. N. M.; Leclère, M.; Stogaitis, N.; Fallis, A. G. Org. Lett. 2010, 12, 1684. doi:10.1021/ol100150f

19. Miege, F.; Meyer, C.; Cossy, J. Org. Lett. 2010, 12, 248. doi:10.1021/ol9025606

20. Schrock, R. R.; Hoveyda, A. H. Angew. Chem., Int. Ed. 2003, 42, 4592. doi:10.1002/anie.200300576

21. Trnka, T. M.; Grubbs, R. H. Acc. Chem. Res. 2001, 34, 18. doi:10.1021/ar000114f

22. Vincent, G.; Kouklovsky, C. Chem. - Eur. J. 2011, 17, 2972. doi:10.1002/chem.201002558

23. Gao, F.; Stamp, C. T. M.; Thoenton, P. D.; Cameron, T. S.; Doyle, L. E.; Miller, D. O.; Burnell, D. J. Chem. Commun. 2012, 48, 233. doi:10.1039/C1CC15452D

24. Malik, C. K.; Hossain, M. F.; Ghosh, S. Tetrahedron Lett. 2009, 50, 3063. doi:10.1016/j.tetlet.2009.04.033

25. Woodward, R. B.; Katz, T. J. Tetrahedron 1959, 5, 70 doi:10.1016/0040-4020(59)80072-7

26. Rosenblum, M. J. Am. Chem. Soc. 1957, 79, 3179. doi:10.1021/ja01569a050

27. Lin, H.-C.; Wu, H.-J. J. Chin. Chem. Soc. 2009, 56, 1072. doi:10.1002/jccs.200900155

28. Álvarez, C.; Peláez, R.; Medarde, M. Tetrahedron 2007, 63, 2132. doi:10.1016/j.tet.2007.01.001

29. Yamaguchi, T.; Ono, T. Chem. Ind. 1968, 769.

30. Crivello, J. V.; Song, S. Chem. Mater. 2000, 12, 3674. doi:10.1021/cm000556l

31. Corey, E. J.; Suggs, W. Tetrahedron Lett. 1975, 16, 2647. doi:10.1016/S0040-4039(00)75204-X

32. Shao, C.; Yu, H.-J.; Wu, N.-Y.; Feng, C.-G.; Lin, G.-Q. Org. Lett. 2010, 12, 3820. doi:10.1021/ol101531r

33. CCDC-1403298 contains the supplementary crystallographic data for this paper. This data can be obtained free of charge from The Cambridge Crystallographic Data Centre via http://www.ccdc.cam.ac.uk/data_request/cif.

\section{License and Terms}

This is an Open Access article under the terms of the Creative Commons Attribution License

(http://creativecommons.org/licenses/by/2.0), which permits unrestricted use, distribution, and reproduction in any medium, provided the original work is properly cited.

The license is subject to the Beilstein Journal of Organic Chemistry terms and conditions:

(http://www.beilstein-journals.org/bjoc)

The definitive version of this article is the electronic one which can be found at:

doi:10.3762/bjoc. 11.163 